\title{
ANALISA FRAMING PEMBERITAAN JOKOWI DALAM PEMBERANTASAN KORUPSI TERKAIT REVISI UNDANG - UNDANG KPK DALAM MEDIA BERITA ONLINE TEMPO.CO
}

\author{
Roos Yuliastina ${ }^{1}$ \\ Dosen Fakultas Ilmu Sosial dan Ilmu Politik Universitas Wiraraja Sumenep \\ yuliastina07@gmail.com \\ Mohammad Bagus Kurniawan ${ }^{2}$ \\ Pasca Sarjana Ilmu Kepolisian
}

\begin{abstract}
Abstrak
Framing secara umum dapat dipahami sebagai metode untuk melihat bagaimana sebuah media bercerita (story telling) atas sebuah peristiwa. Cara bercerita itu tergambar pada "cara melihat" realitas yang dijadikan berita. Analisis Framing dalam kasus pemberitaan Jokowi terkait revisi UU KPK, menggunakan teori framing model Gamson \& Modigliani dimana analisis framing indikator analisis framing devices, Metaphors, Exemplar, Catchphrases, Depictions, Visual Images, Reasoning device, Roots dan Appeal to principle.

Hasil analisis pada kasus ini, menunjukkan bahwa media massa khususnya media massa online tempo.co menggambarkan dan mendeskripsikan kritikan keras terhadap kebijakan Jokowi yang tidak merevisi UU KPK meskipun gejolak masa dan penolakan masyarakat terhadap peraturan kelembagaan yang dianggap melemahkan peran KPK dalam memberantas korupsi. Permasalahan ini yang kemudian diangkat dan dijadikan topik hangat sebagai bentuk kritik dan protes kepada Jokowi selaku presiden RI dalam menanggapi permasalahan perubahan UU revisi KPK.
\end{abstract}

Kata Kunci: Analisis framing, Jokowi dan Tempo.co

\section{PENDAHULUAN}

Dalam formulasi yang dibuat oleh Gamson dan Modigliani, frame dipandang sebagai cara bercerita atau gugusan ide-ide yang tersusun sedemikian rupa dan menghadirkan konstruksi makna dari peristiwa yang berkaitan dengan suatu wacana. Gamson melihat wacana media (khususnya berita) terdiri atas sejumlah kemasan (package) melalui konstruksi atas suatu peristiwa dibentuk. Kemasan itu merupakan skema atau struktur pemahaman yang dipakai oleh seseorang ketika mengkonstruksikan pesan-pesan yang dia sampaikan dan menafsirkan pesan yang dia terima. Selain itu, framing secara umum dapat dipahami sebagai metode untuk melihat bagaimana sebuah media bercerita (story telling) atas sebuah peristiwa. Cara bercerita itu tergambar pada "cara melihat" realitas yang dijadikan berita Ada dua perangkat bagaimana ide-ide tersebut dapat diterjemahkan dalam teks berita yaitu :

1. Framing Device (perangkat framing), yaitu perangkat yang berhubungan dan berkaitan langsung dengan ide sentral atau bingkai yang ditekankan dalam teks berita. Perangkat framing ini ditandai dengan pemakaian kata, kalimat, grafik/gambar dan metafora tertentu. 
2. Reasoning Device (perangkat penalaran) yaitu sebuah gagasan tidak hanya berisi kata atau kalimat, gagasan itu juga selalu ditandai oleh dasar pembenar tertentu, alasan tertentu dan sebagainya. Dasar pembenaran dan penalaran tersebut bukan hanya meneguhkan suatu gagasan atau pandangan, melainkan lebih jauh membuat pendapat atau gagasan tampak benar, absah dan demikian adanya. Lewat aspek penalaran tersebut, khalayak akan menerima pesan itu sehingga tampak sebagai kebenaran, alamiah dan wajar. Sebaliknya, kalau dalam suatu teks tidak terdapat elemen penalaran demikian, gagasan akan tampak aneh, tidak beralasan dan orang dengan mudah mempertanyakan pesan atau gagasan tersebut.

Gamson mendefinisikan Core Frame sebagai organisasi gagasan sentral atau alur cerita yang mengarahkan makna peristiwaperistiwa yang dihubungkan dengan suatu isu. Frame merupakan inti sebuah unit besar wacana publik yang disebut package 


\begin{tabular}{|c|c|}
\hline \multicolumn{2}{|c|}{$\begin{array}{c}\text { Struktur Dalam Framing } \\
\text { Model Gamson \& Modigliani } \\
\text { Media Package }\end{array}$} \\
\hline \multicolumn{2}{|c|}{ Core Frame } \\
\hline \multicolumn{2}{|c|}{ Condensing Symbols } \\
\hline $\begin{array}{l}\text { FRAMING DEVICES } \\
\text { (Perangkat Framing) }\end{array}$ & $\begin{array}{c}\text { REASONING DEVICES } \\
\text { (Perangkat Penalaran) }\end{array}$ \\
\hline $\begin{array}{c}\text { Metaphors } \\
\text { (Perumpamaan /pengandaian atau } \\
\text { kata yang bukan sebenarnya) }\end{array}$ & $\begin{array}{c}\text { Roots } \\
\text { (Hubungan Sebab-Akibat dari } \\
\text { pemberitaan) }\end{array}$ \\
\hline $\begin{array}{c}\text { Exemplar } \\
\text { (Kasus-kasus yang banyak } \\
\text { diekspos media atau yang dijadikan } \\
\text { pelajaran) }\end{array}$ & $\begin{array}{c}\text { Appeal to Principle } \\
\text { (Penggambaran prinsip, pemikiran dan } \\
\text { sikap deskriptif) }\end{array}$ \\
\hline $\begin{array}{c}\text { Catchphrases } \\
\text { (Frase yang menarik, menggunakan } \\
\text { konotasi tertentu sperti jargon- } \\
\text { jargon, slogan pemeo dan } \\
\text { semboyan) }\end{array}$ & \\
\hline $\begin{array}{c}\text { Depictions } \\
\text { (Penggambaran suatu obyek, isu, } \\
\text { peristiwa dan fakta atau orang yang } \\
\text { bersifat konotatif) }\end{array}$ & \\
\hline $\begin{array}{c}\text { Visual Images } \\
\text { (Gambaran yang diberikan berupa } \\
\text { foto, lukisan atau rangkaian dari } \\
\text { kata-kata/polisemi yang melukiskan } \\
\text { sesuatu) }\end{array}$ & \\
\hline
\end{tabular}


2. PEMBAHASAN ANALISIS FRAMING

A. MEDIA PACKAGE

Media Online tempo.co (https://www.tempo.co) dalam fokus beritanya sekitar belasan kali mengangkat berita terkait "Sikap" Jokowi terhadap Revisi Undang-undang KPK, yang dimuat tempo.co sekitar tanggal 9 September 2019 sampai dengan 19 September 2019.

B. CORE FRAME
Elemen inti media online tempo.co adalah terkait Revisi Undang-Undang KPK yang menimbulkan pro dan kontra mulai dari Internal KPK, Eksekutif maupaun Legislatif, dalam tulisan ini penulis mencoba menganalisis framing menggunakan model Gamson dan Modigliani dengan fokus pemberitaan terkait Presiden Jokowi terhadap Revisi UU KPK.

URL:

https://www.tempo.co/search?q=jokowi+rev isi+uu+kpk\#gsc.tab=0\&gsc. $q=$ jokowi $\% 20 \mathrm{re}$ visi $\% 20 \mathrm{u} \mathrm{u} \% 20 \mathrm{kpk} \& \mathrm{gsc}$.page $=3$

\section{TEMPO.CO}

HOME NASIONAL BISNIS METRO DUNIA BOLA CANTIK $~$ TEKNO OTOMOTIF $\sim$ FOTO VIDEO KOLOM INDEKS KEMENKO PMK LAINNYA

\section{Search}

jokowi revisi uu kpk

About 361,000 results $(0.30$ seconds)

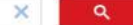

Pakar Hukum Sebut Sikap Jokowi Soal Revisi UU KPK Menyesatkan

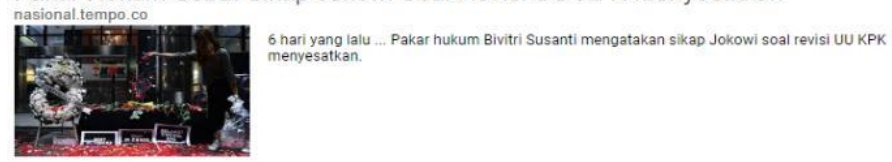

Analisa Fahri Hamzah Mengenai Sikap Jokowi dan Revisi UU KPK .

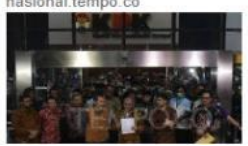

3 hari yang Ialu. -Usulan revisi UU KPK meskipun ada tekanan
sipilit, tapi Presiden Jokowi tetap pada keputusannya menyetujulu

\section{CONDENSING SYMBOLS}

1. Framing Devices:

1). Metaphors

Perumpamaan, pengandaian atau kata yang mengandung kata bukan sebenarnya. Dalam berita tempo.co yang dimuat pada hari selasa tanggal 15 September 2019, dengan headline "Revisi UU KPK, Bola di Tangan Tuan Presiden”, jika di analisis menggunakan analisis framing dari aspek Metaphor atau penggunaan perumpamaan dapat diketahui jika pihak tempo ingin menyampaikan pesan dengan menggunakan kata perumpamaan "bola di tangan tuan presiden" bahwa presiden Jokowi terkait Revisi UU KPK seolah-olah presiden lah pemegang kekuasaan "penuh" saat ini untuk jadi atau tidaknya UU KPK direvisi walaupun pada saat berita di muat belum ada pengesahan dari Legislatif, pengambil keputusan tentang pelaksanaan Revisi UU KPK.

URL:

https://fokus.tempo.co/read/1248420/revisiuu-kpk-bola-di-tangan-tuan-presiden. 


\section{TEMPO.CO}

FOKUS

HOME NASIONAL BISNIS METRO DUNIA BOLA CANTIK TEKNo OTOMOTIF FOTO VIDEO KOLOM INDEKS KEMENKO PMK LAINNYA

Iklan ditutup oleh Google

HOME > FOKUS, FOKUS

\section{Revisi UU KPK, Bola di Tangan Tuan Presiden}

Reporter: Shinta Maharani (Kontributor)

Senin, 16 September 201913.37 WIB

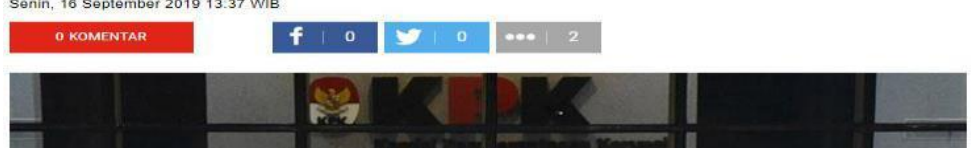

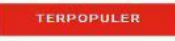

Demo Mahasiswa. Kekecewaaan Berujung
Parlemen Jalanan

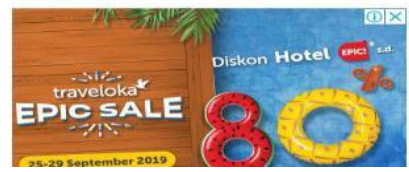

janji presiden degan perumpamaan kata "Janji Tinggal Janji", yang menyiratkan terkait "janji” politik saat Presiden Jokowi melakukan kampanyenya terhadap pemberantasan korupsi.
Majalah Tempo juga sempat membuat cover majalah tempo dengan gaya mengkritik sikap Jokowi yang dianggap "ingkar janji”. Dengan menggunakan topik utama managih

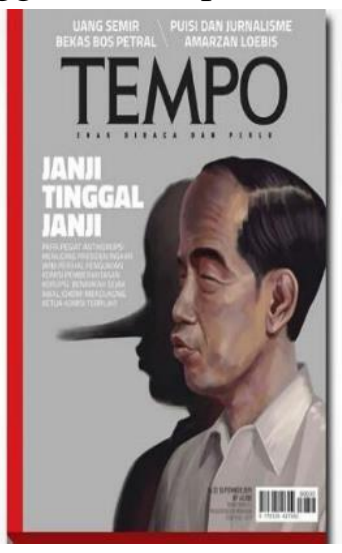

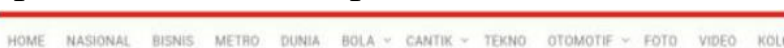
Font Roboto Ukverian Font an

'Menurut saya sih masih dalam batas wajar. Masih oke. Tak ada sama sekali penghinaan. Justru seharusnya direspons baik,' kata Ade saat dihubungi Tempo, Selasa, 17 September 2019. Sampul bergambar Presiden Jokowi yang memiliki bayangan berhidung panjang sempat memunculkan wacana dilaporkan ke Kepolisian sebagai bentuk penghinaan kepada presiden.

Menurut Ade, bagi LBH Pers cover itu produk jurnalistik yang wajar. Saat ini, Jokowi memang sedang menuai banyak sorotan terhadap sikapnya yang menyepakati Revisi Undang-Undang Nomor 30 Tahun 2002 tentang Komisi Pemberantasan Tindak Pidana Korupsi.

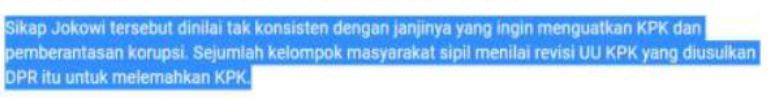

Dalam bayangan saya Tempo menangkap fenomena itu dan ditafsirkan dalam bentuk gambar yang ada di cover itu, yang pinokio itu. Dalam konteks demokrasi itu sangat wajar,' tutur Ade.

Dia mengingatkan masyarakat bahwa Jokowi merupakan Presiden yang dipilih rakyat dan bukan

\section{2). Catchphrases}

\section{TEMPO.CO}

rukus

Perorangan Hingga Korporasi Jadi Tersangka Kasus Kebakaran Hutan

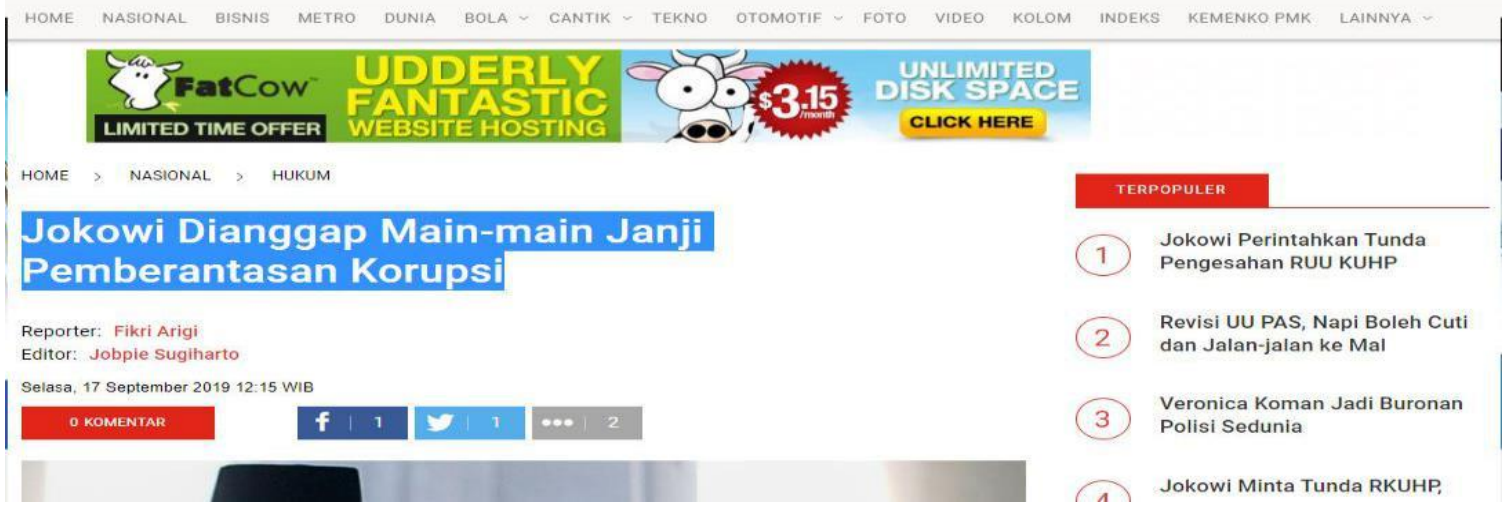

Tempo.co edisi ; Selasa, 17 September 2019 
Catchphrases adalah Frase yang menonjolkan Konotasi tertentu. Dalam hal ini adalah frase khas yang merujuk pemikiran tertentu. Wujud jargon-jargon, slogan pemeo dan semboyan. Ketidak tegasan presiden dalam revisi UU KPK jiga diuangkapkan kembali dalam berita edisi 17 September dengan judul "Jokowi Dianggap Main - Main Janji Pemberatasan Korupsi”, perumpamaan "Main - Main" dalam hal ini menunjukkan jika redaksi ingin menyampaikan bahwa ketidak seriusan atau ketidak konsistenan pak Presiden terhadap janjinya sendiri. Dalam isi berita juga dapat dilihat pada Alinea ke empat yang memuat komentar Ketua YLBHI yaitu : “Asfinawati menuding Presiden Jokowi telah membohongi publik karena terlibat dalam pelemahan KPK dengan membahas revisi UU KPK”.

\begin{tabular}{l}
\hline HOME NASIONAL BISNIS METRO DUNIA BOLA $\checkmark$ CANTIK $\checkmark$ TEKNO OTOMOTIF $\checkmark$ FOTO VIDEO KOLOM \\
\hline O KOMENTAR \\
SUrpres ItU DerISI persetujuan mempanas DerIKUt menterı yang aImInta membanas Dersama DFR. \\
Yayasan Lembaga Bantuan Hukum Indonesia (YLBHI) meminta Jokowi tidak main-main dengan \\
janjinya memberantas korupsi. \\
Ketua Umum YLBHI Asfinawati menuding Presiden Jokowi telah membohongi publik karena terlibat \\
dalam pelemahan KPK dengan membahas revisi UU KPK. \\
Dia mengatakan bahwa Presiden Jokowi pernah berjanji tak akan kompromi dengan pemberantasan \\
korupsi. Bahkan menyebut korupsi sebagai musuh bersama. \\
"Mandat rakyat yang telah diperoleh, salah satunya melalui kampanye keberpihakan terhadap \\
pemberantasan korupsi," ucap Asfinawati.
\end{tabular}

URL: https://nasional.tempo.co/read/1248808/jokowi-dianggap-main-main-janjipemberantasan-korupsi/full\&view $=\mathrm{ok}$

3). Exemplars

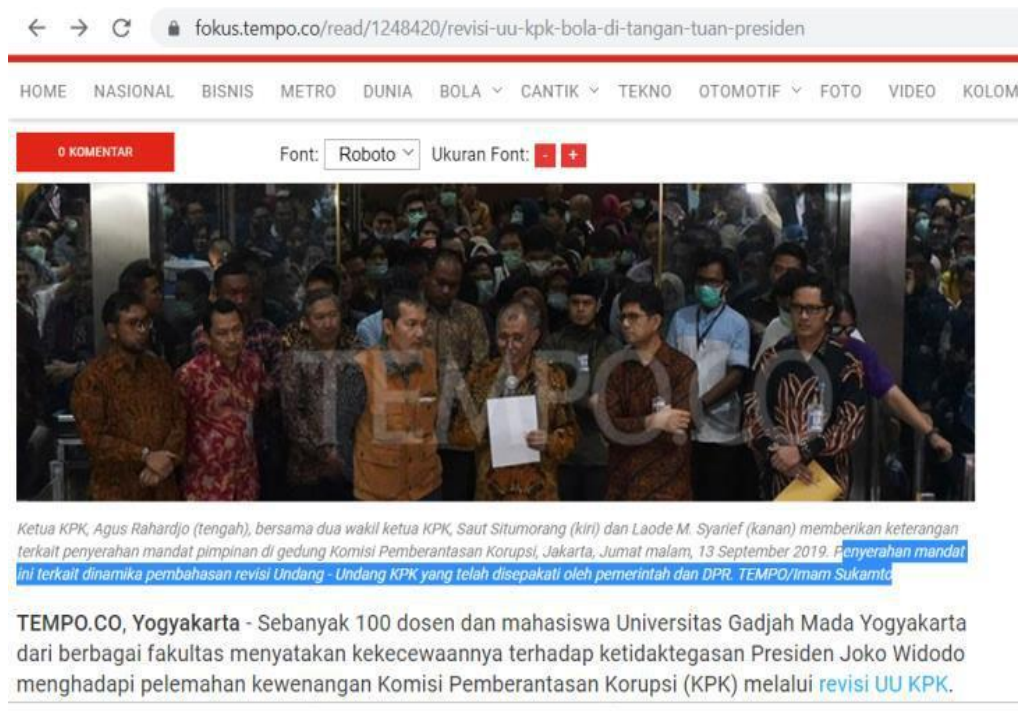

Exemplars yang dimaksud adalah Kasus-kasus yang banyak diekspos media atau yang dijadikan pelajaran, salah satunya adalah media online Tempo.co yang secara kontinyu menayangkan berita - berita terkini terkait kasus Revisi UU KPK. Sebagaimana yang dimuat dalam media online Tempo.co dalam edisi 13 September 2019. Dimana ada kejadian Ketua KPK, Agus Rahardjo, bersama dua wakil ketua KPK, Saut Situmorang dan Laode M. Syarief memberikan penyerahan mandate pimpinan di gedung Komisi Pemberantasan 
Korupsi, di Jakarta, pada Jumat malam tanggal 13 September 2019.

Kejadian ini yang kemudian menimbulkan pemberitaan negatif terhadap presiden Jokowi, karena Presiden dianggap menggantung atau tidak tegas untuk menolak revisi UU KPK, atau dengan kata lain media Tempo.co mulai gencar mengkritik Jokowi karena dianggap tidak menepati janji untuk memberantas korupsi.

\section{4). Depiction}

Penggambaran suatu obyek, isu, peristiwa dan fakta atau orang yang bersifat konotatif. Adanya penggunaan kata khusus untuk membangkitkan prasangka yang menyesatkan. Dalam hal ini terkait kasus pemberitaan revisi UU KPK, framing berita Tempo.co lebih mengarahkan pada kritik terhadap presiden Jokowi selaku kepala negara yang tidak bisa mengambil sikap tegas. Hal ini dapat dilihat dari tulisan tulisan di media Tempo.co yang beberapa hari terakhir menggambarkan sosok presiden Jokowi yang menurut pemberitaan Tempo.co tidak konsisten perihal janji penguatan KPK dengan sikap presiden yang tidak mencaput Surpres (Surat Presiden) terkait Revisi UU KPK.

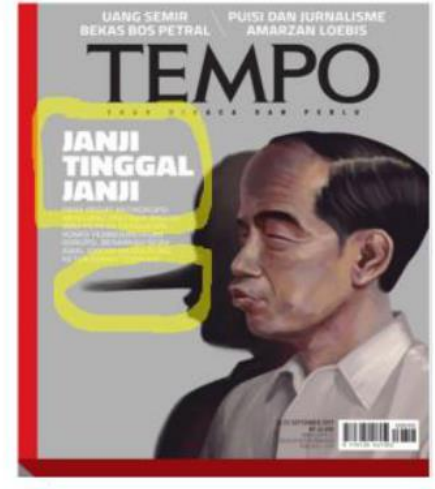

$\leftarrow \rightarrow C$ cekfakta.tempo.co/fakta/400/fakka-atau-hoaks-benarkah-cover-majalah-tempo-edisi-16-septembe
HOME NASIONAL BISNIS METRO DUNIA BOLA $\sim$ CANTIK $\sim$ TEKNO OTOMOTIF $\sim$ FOTO VIDEO KOL Majalah Tempo tidak pernah menerbitkan edisi "Saya Tetap Percaya Presiden" sebagaimana yang beredar di media sosial untuk menggantikan edisi "Janji Tinggal Janji". Dalam laman resmi Majalah Tempo, edisi terakhir yang diterbitkan adalah edisi 'Janij Tinggal Janij'.

Menurut Pemimpin Redaksi Tempo.co, Wahyu Dhyatmika, secara gramatikal, judul "Saya Masih Percaya Presiden" itu salah. "Saya di sana mewakili siapa? Redaksi Tempo? Narasumber?" kata Wahyu. Dia menegaskan Tempo tidak mungkin melakukan kesalahan elementer seperti itu.

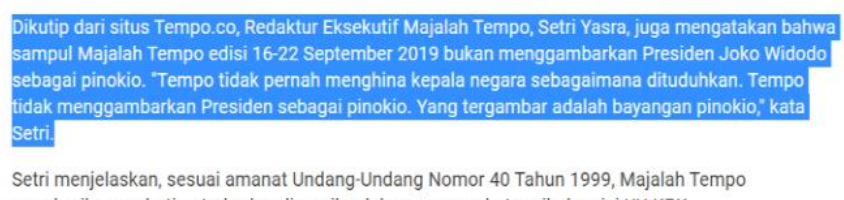
memberikan perhatian terhadap dinamika dalam masyarakat perihal revisi UU KPK.

la mengatakan, sampul Majalah Tempo dengan judul "Janji Tinggal Janji" itu merupakan metafora atas dinamika tersebut, yaitu tudingan sejumlah pegiat antikorupsi bahwa Presiden ingkar janji

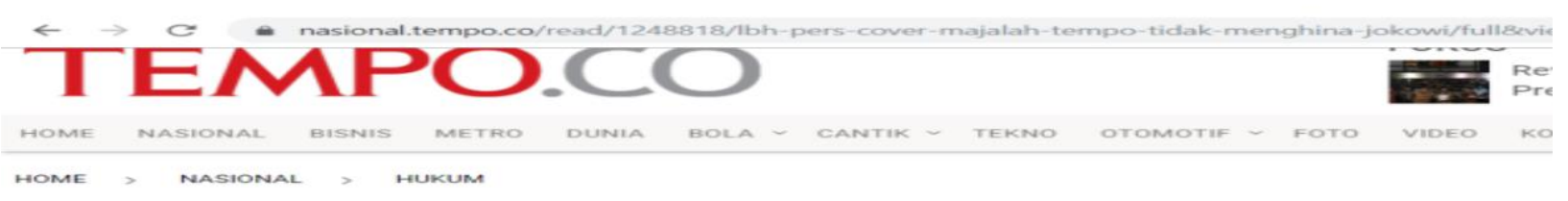

\section{LBH Pers: Cover Majalah Tempo Tidak Menghina Jokowi}

Reporter: Egi Adyatama
Editor: Jobpie Sugiharto

Setasa, 17 September 2019
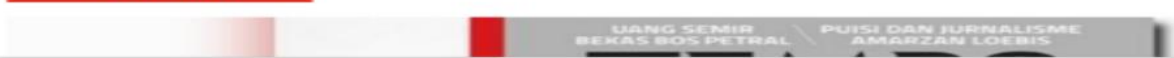

Penggunaan gambar bayangan hidung panjang menyerupai tokoh Pinokio, "Tidak Menghina", merupakan topik utama Tempo.co pasca kasus pelimpahan mandat wewenang KPK ke pada Presiden. Menurut Redaktur Eksekutif Majalah Tempo, Setri Yastra, menurutnya sampul majalah Tempo edisi 16-22 Septermber 2019 bukan menggambarkan Presiden Joko Widodo sebagai Pinokio, yang tergambar melainkan bayangan Pinokio menurut Sentri. Jika di analisis lebih jauh, tentu saja penggunaan gambar dan kata - kata "Janji Tinggal Janji" tersebut menyiratkan prasangka negatif bagi publik yang membaca berita tersebut. Karena dalam persepsi publik pertama kali yang di ingat atau dipahami dari judul tersebut adalah antara tindakan dan janji yang di berikan Jokowi terbukti tidak sesuai, dan dipertegas melalui konotasi bayangan tokoh fiksi "Pinokio" yang apabila berbohong akan bertambah panjang hidungnya. 
5). Visual Image

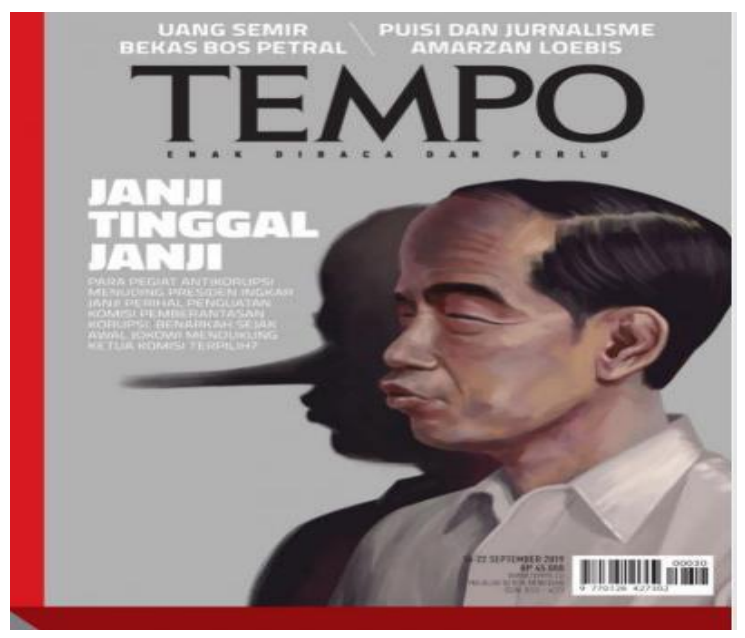

Pada perseptif ini, analisis framing dari pemberitaan media online Tempo.co secara visual mempertegas gambaran secara keselurahan kasus Revisi UU KPK yang telah disteujui oleh DPR beserta pemerintah RI yang diwakilkan oleh figur presiden Jokowi. Penggunaan desain visual gambar Jokowi beserta bayangan Pinokio menunjukkan bahwa ketegasan penulis berita ingin meyampikan baik secara kata dan gambar bahwa kasus ini menunjukkan siapa sebetulnya Jokowi melalui bayangan Pinokio yang berhidung panjang ketika berbohong.

\section{Reasoning Devices:}

1). Roots

Roots adalah analisis kausal yang biasanya adalah sebuah unsur sebab akibat. Dalam berita online Tempo.co juga menampilkan roots sebagai berikut :

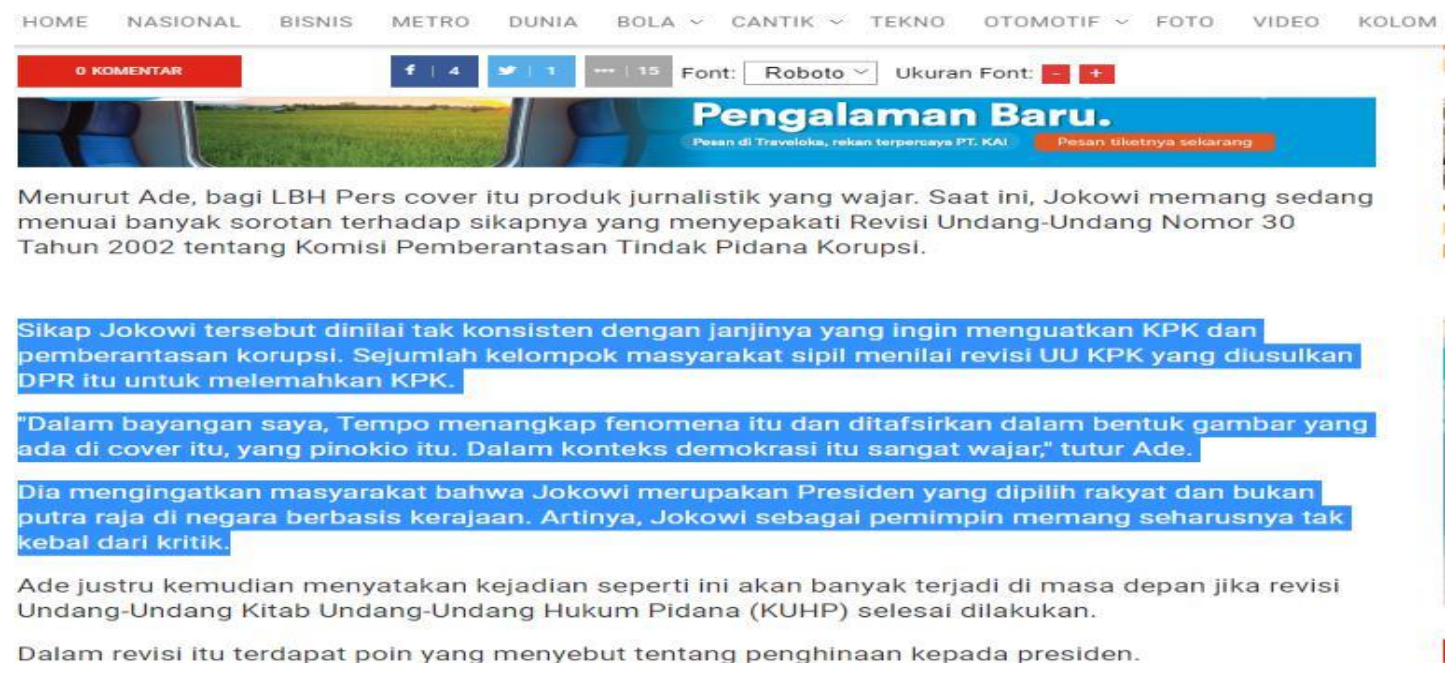

Yang dalam bertita tersebut tempo berbentuk bayangan Pinokio menampilkan statement LBH Pers Cover merupakan hal yang wajar dalam konteks yang menyatakan pemberitaan tentang Presiden Jokowi dalam terkait revisi UU KPK terkait sikap Jokowi yang dinilai tidak konisiten dengan janjinya yang ingin menguatkan KPK dan pemberantasan korupsi. Gambar dalam cover majalah demokrasi, dimana ditafisrkan sebagai bentuk kritik. URL : https://nasional.tempo.co/read/1248818/lbhpers-cover-majalah-tempo-tidak-menghinajokowi/full\&view $=$ ok 
2). Appeal To Principle

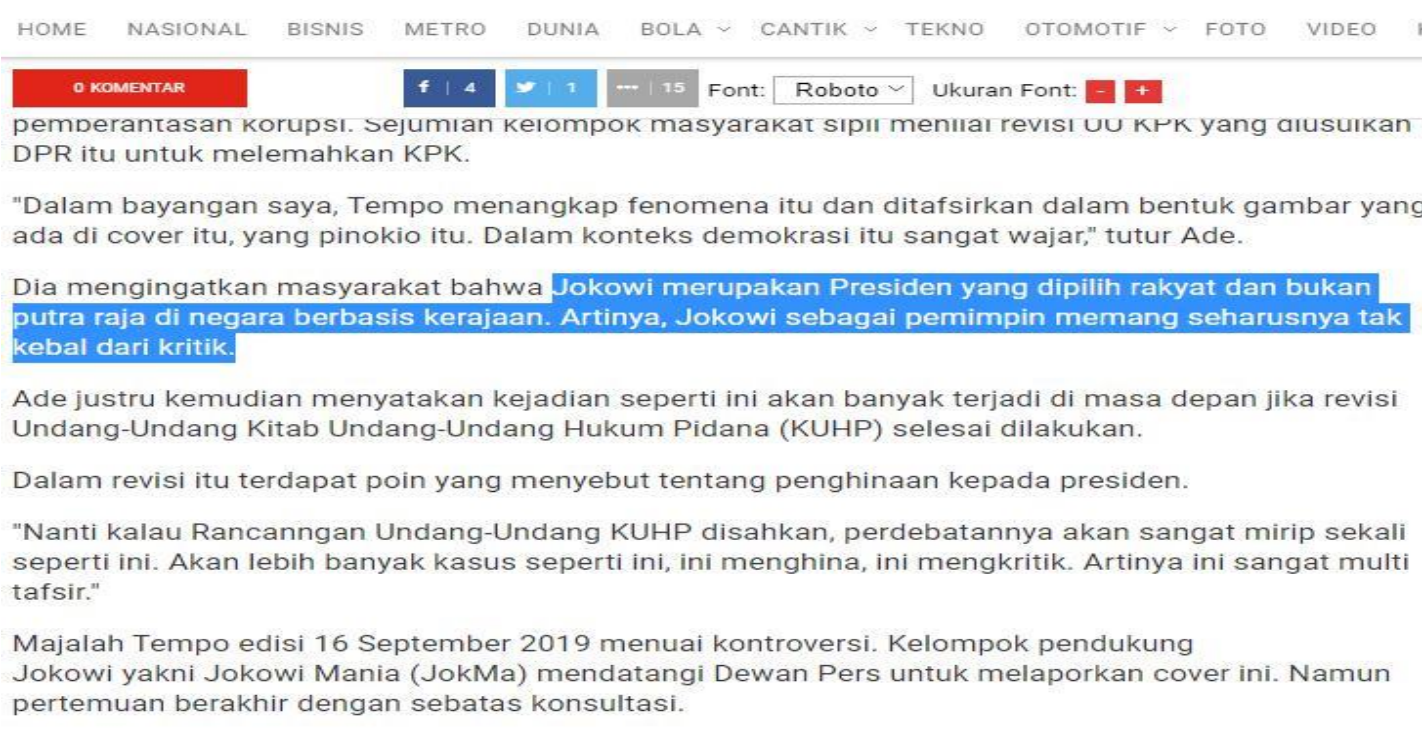

Appeals to Principle adalah premis dasar atau klaim-klaim moral seperti dalam pemberitaan, dalam pemberitaan di atas (masih sama pada tangkapan gambar roots) juga terdapat Appeals to Principle yang dimuat dalam frase kata-kata pendapat Direktur Umum Lembaga Bantuan Hukum (LBH) Pers Ade Wahyudi yang mengingatkan masyarakat Indonesia bahwa Presiden Jokowi merupakan hasil dari pilihan rakyat dan bukan putra raja pada negara yang berbasis kerajaan, yang mana seharusnya pemimpin negara berdemokrasi tidak kebal dari kritik.

\section{Kesimpulan}

Teknologi dan perkembangan internat seperti dua sisi mata uang yang tidak dapat dipisahkan, satu sisi kecanggihan tehnologi dan kemudahan mengakses internet memberikan dampak positif, namun di sisi lain juga memberikan dampak negatif. Dampak negatif yang dimaksud adalah, masyarakat yang dapat mengakases berita dan informasi secara bebas melalui gadget dan jaringan internet, namun terkadang tidak diimbangi dengan kemampuan berfikir kritis dan bijak dalam menyaring informasi yang diterima.

Dalam kasus ini, berdasarkan analisis framing pemberitaan Jokowi terkait pemberantasan korupsi dan rencana merevisi UU KPK yang kemudian dikaitkan dengan janji politik kampanye Jokowi. Pada dasarnya media massa ataupun media online memiliki kekuatan dalam mempengaruhi atau menggiring opini publik yang menerima informasi tersebut. Hal yang harus di perhatikan adalah kemampuan audiens atau oarang yang menerima informasi harus selektif dan bijak dalam memilih informasi yang diberitakan melalui media massa khususnya media online. 


\section{DAFTAR PUSTAKA}

Tempo.co. Jokowi Revisi Undang -Undang KPK: Media Online: https://www.tempo.co/search?q=jokowi+rev isi+uu+kpk\#gsc.tab=0\&gsc.q=jokowi\%20re visi $\% 20 \mathrm{u} \% 20 \mathrm{u} \% 20 \mathrm{kpk} \& \mathrm{gsc}$. sort $=$

Tempo.co. Revisi UU KPK, Bola ditangan Presiden. Media Online: https://fokus.tempo.co/read/1248420/revisiuu-kpk-bola-di-tangan-tuan-presiden

Tempo.co. Jokowi dianggap main - main berantas korupsi. Media online: https://nasional.tempo.co/read/1248808/joko wi-dianggap-main-main-janjipemberantasan-korupsi/full\&view=ok

Tempo.co. Majalah Tempo tidak Hina Jokowi

https://nasional.tempo.co/read/1248818/lbhpers-cover-majalah-tempo-tidak-menghinajokowi/full\&view $=$ ok 